DOI: 10.18276/sip.2016.44/3-21

\title{
Barbara Wieliczko*
}

Instytut Ekonomiki Rolnictwa i Gospodarki Żywnościowej

Państwowy Instytut Badawczy

\section{JAKI MECHANIZM REDUKCJI EMISJI GAZÓW CIEPLARNIANYCH ZASTOSOWAĆ W ODNIESIENIU DO ROLNICTWA UNII EUROPEJSKIEJ?}

\begin{abstract}
Streszczenie
Rolnictwo jest głównym emitentem gazów cieplarnianych innych niż $\mathrm{CO}_{2}$. W związku z tym także i ten sektor unijnej gospodarki zostanie w najbliższych latach objęty rozwiązaniami mającymi na celu ograniczenie tych emisji. Celem artykułu jest przedstawienie skali i charakteru emisji gazów cieplarnianych w rolnictwie Unii Europejskiej oraz ocena, jaki mechanizm redukcji emisji tych gazów byłby najwłaściwszy, biorąc pod uwagę specyfikę sektora rolnego. Badanie opiera się na metaanalizie wyników różnych badań z zakresu redukcji emisji zanieczyszczeń. Wyniki pokazują, iż stosowany w odniesieniu do innych sektorów system handlu prawami do emisji wydaje się nie być rozwiązaniem pasującym do całego rolnictwa Unii Europejskiej. Najwłaściwsze byłoby wprowadzenie zestawu kilku rozwiązań dostosowanych do wielkości i charakteru emisji gazów cieplarnianych danego gospodarstwa rolnego.
\end{abstract}

Słowa kluczowe: rolnictwo, emisja gazów cieplarnianych, Unia Europejska

\footnotetext{
* Adres e-mail: Barbara.Wieliczko@ierigz.waw.pl.
} 


\section{Wprowadzenie}

Gazy cieplarniane obejmują różne gazy generowane przez wszystkie sektory gospodarki, w tym także rolnictwo. Od 2005 roku sektory będące kluczowymi emitentami gazów cieplarnianych w Unii Europejskiej są objęte systemem handlu uprawnieniami do emisji ${ }^{1}$, jednak rolnictwo, podobnie jak transport, nie zostało objęte tym systemem. Komisja Europejska w planie prac na 2016 roku zapowiedziała przedstawienie projektu regulacji zawierającej rozwiązania odnoszące się do „wspólnego wysiłku redukcyjnego dla sektorów nieobjętych systemem handlu uprawnieniami do emisji” (Komisja Europejska, 2015)².

Celem artykułu jest przedstawienie problemu wyboru mechanizmu włączenia rolnictwa do ograniczania emisji gazów cieplarnianych. Opracowanie opiera się na analizie wyników innych badań dotyczących skali i charakteru emisji gazów cieplarnianych oraz mechanizmów służących nakłonieniu emitentów takich gazów do redukcji generowanego ich poziomu. W pierwszej części artykułu zaprezentowano problem emisji gazów cieplarnianych w rolnictwie Unii Europejskiej, zaś w drugiej części omówiono systemem stosowany w Unii do redukcji emisji w innych sektorach gospodarki oraz wybrane alternatywne rozwiązania mogące mieć zastosowanie $\mathrm{w}$ rolnictwie.

\section{Emisja gazów cieplarnianych w rolnictwie Unii Europejskiej}

Rolnictwo emituje różne gazy cieplarniane, jednak głównie inne niż $\mathrm{CO}_{2}$, który jest najpowszechniej emitowanym przez gospodarkę gazem prowadzącym do zmian klimatu. Sektor rolny jest przede wszystkim emitentem metanu $\left(\mathrm{CH}_{4}\right)$ wytwarzanego przez zwierzęta. Poza $\mathrm{CH}_{4}$ rolnictwo generuje również znaczne ilości tlenku diazotu $\left(\mathrm{N}_{2} \mathrm{O}\right)$, który uwalnia się podczas nawożenia gleby sztucznymi nawozami azotowymi oraz w czasie rozkładania się odchodów zwierząt ${ }^{3}$. Rolnictwo Unii Europejskiej

1 Systemy handlu prawami do emisjami określane są jako systemy „ograniczaj i handluj” (cap-and-trade).

2 Komisja Europejska przeprowadziła w 2015 r. konsultacje społeczne na temat emisji gazów cieplarnianych w rolnictwie. Ich szczegóły i wyniki znajdują się na stronie: http://ec.europa.eu/clima/ consultations/articles/0026_en.htm (14.10.2016).

3 Należy zaznaczyć, że zgodnie z nomenklaturą określoną przez Intergovernmental Panel for Climate Change gazy cieplarniane emitowane przez maszyny i urządzenia wykorzystywane w rolnic- 
odpowiada za około 10,1\% gazów cieplarnianych emitowanych przez Wspólnotę. Szacuje się, iż $58 \%$ rolniczej emisji gazów cieplarnianych to $\mathrm{N}_{2} \mathrm{O}$, a pozostałe $42 \%$ to $\mathrm{CH}_{4}$ (Fellmann i in., 2015, s. 17). Poziom rolniczych emisji ma w poszczególnych krajach Unii różny udział w strukturze emisji gazów cieplarnianych. Najwyższy odnotowano w Irlandii (30,8\%), zaś najniższy na Malcie (2,3\%) (Fellmann i in., 2015, s. 19). Widoczny jest trend spadkowy w poziomie emisji gazów cieplarnianych generowanych przez unijne rolnictwo, co wynika przede wszystkim ze wzrostu produktywności i spadku pogłowia bydła, jak również wdrażania praktyk rolniczych prowadzących do ograniczenia negatywnego oddziaływania sektora na środowisko (Dominguez i in., 2012, s. 30).

Poziom emisji gazów cieplarnianych w rolnictwie zależy przede wszystkim od typu prowadzonej działalności rolniczej. Generalnie produkcja zwierzęca odpowiada za znacznie większe emisje zanieczyszczeń powietrza niż produkcja roślinna. Jednak występują znaczne różnice między poszczególnymi gatunkami zwierząt. Najwięcej metanu produkuje bydło i owce, a znacznie mniej konie czy świnie. Wpływ na skalę emisji metanu ma nie tylko gatunek zwierzęcia, ale także wiek czy rodzaj otrzymywanej paszy. Natomiast naturalne nawozy generują zarówno metan, jak i diazot. W przypadku gleb użytkowanych rolniczo mamy do czynienia z naturalnymi procesami zwiększania i spadku zawartości azotu oraz nawożenia przez człowieka. Procesy te prowadzą do wzrostu poziomu emitowanego $\mathrm{N}_{2} \mathrm{O}$. W Unii Europejskiej ponad połowę emisji gazów cieplarnianych w rolnictwie powodują gleby użytkowane rolniczo (52\% emisji w ekwiwalencie $\left.\mathrm{CO}_{2}\right)$, kolejne $32 \%$ stanowią emisje związane z fermentacją jelitową, 15\% przypada na gospodarkę nawozem naturalnym, a 1\% to uprawa ryżu (Fellmann i in., 2015, s. 23).

Zmniejszenie poziomu emitowanych gazów cieplarnianych może być osiągnięte na wiele sposobów przy jednoczesnym utrzymaniu skali produkcji rolnej. Wśród możliwych działań znajdują się zmiany dotyczące: sposobu prowadzenia upraw, zarządzania trwałymi użytkami zielonymi, sposobu prowadzenia chowu i hodowli zwierząt oraz utylizacji ich odchodów.

twie nie są uwzględniane jako emisje pochodzące z rolnictwa, ale są włączone do kategorii „energia”, zaś produkcja pasz i nawozów dla rolnictwa do kategorii „procesy przemysłowe” (IPCC, 2006). Jednak $\mathrm{w}$ wielu badaniach nad ograniczaniem negatywnego wpływu rolnictwa na środowisko uwzględnia się również i te elementy, np. (McLeod, Eory, Gruère, Lankoski, 2015, s. 7. 


\section{System handlu prawami do emisji czy specjalne rozwiązanie dla rolnictwa?}

Wśród możliwych mechanizmów wprowadzania działań służących ograniczeniu emisji gazów cieplarnianych w rolnictwie znajdują się między innymi: działania informacyjne i edukacyjne, samoregulacja sektora, stworzenie rynku handlu emisjami, opodatkowanie emisji, wdrożenie systemu kwotowania emisji, wprowadzenie regulacji dotyczących praktyk rolniczych czy subsydia. Każda z tych metod ma swoje wady i zalety. W odniesieniu do rolnictwa Unii Europejskiej przy wyborze mechanizmu zmniejszania emisji gazów szczególnie istotne wydaje się uwzględnienie dwóch kwestii - zróżnicowania produkcji rolnej oraz liczby podmiotów prowadzących działalność rolniczą.

Pierwszym rozwiązaniem, które należy rozważyć, jest zastosowanie systemu handlu prawami do emisji na wzór tego już funkcjonującego w Unii Europejskiej. Europejski System Handlu Emisjami (European Trading System - ETS) to pierwszy międzynarodowy system handlu emisjami wdrażany etapami od 2005 roku. Jego celem jest redukcja emisji zanieczyszczeń o $21 \%$ do roku 2020 w stosunku do poziomu emisji z 2005 roku (European Commission, 2015b, s. 12). System obejmuje $50 \%$ unijnych emisji gazów cieplarniach, czyli ponad 12 tys. podmiotów ${ }^{4}$, które mogą między sobą dokonywać obrotu uprawnieniami do emisji i mają możliwość korzystania w tym celu z pośrednictwa aukcji. Możliwe jest również zachowanie niewykorzystanych uprawnień do późniejszego użycia.

System handlu prawami do emisji to rozwiązanie, którego główną zaletą jest pozostawienie podmiotom objętym tym systemem swobody w podejmowaniu decyzji o tym, czy, kiedy oraz w jaki sposób i w jakim tempie dokonają ograniczeń w wielkości emitowanych przez siebie zanieczyszczeń. $\mathrm{Z}$ tego względu rozwiązanie to zapewnia brak gwałtownych zmian w poziomie podaży sektorów nim objętych, co jest szczególnie ważne w przypadku rolnictwa produkującego żywność. Jednocześnie jednak wdrożenie takiego systemu jest czasochłonne i kosztowne. Co więcej, system wymaga od jego uczestników wiedzy o sposobie handlu prawami do emisji i ewentualnego zaangażowania w zakup lub sprzedaż tych praw. Tym samym jest to rozwiązanie, którego wdrożenie może być trudne w przypadku sektora

${ }^{4}$ W systemie uczestniczy 31 państw. Poza państwami UE-28 są to Norwegia, Islandia i Szwajcaria. 
o bardzo dużej liczbie podmiotów o różnym poziomie emisji. Liczba gospodarstw rolnych w Unii Europejskiej wynosi około 12 mln, czyli tysiąc razy więcej niż liczba obecnych uczestników ETS.

Ponadto wyniki dotychczasowych badań na temat funkcjonowania ETS nie zachęcają do skorzystania z tego rozwiązania. Szacuje się, że spadek emisji $\mathrm{CO}_{2}$ jest stosunkowo niewielki i wynosi jedynie około $2-4 \%$ zanieczyszczeń objętych systemem (Laing, Sato, Grubb, Comberti, 2014). Jednocześnie wpływ na podejmowanie działań inwestycyjnych mających na celu ograniczenie poziomu emisji gazów cieplarnianych jest niewielki, na co wskazują badania przywołane w publikacji Lainga Sato, Grubba i Comberti (2014), choć wyniki różnią się w zależności od badania.

Innym rozwiązaniem jest nałożenie na rolnictwo określonych wymogów co do wielkości emisji gazów cieplarnianych. Wyniki analizy różnych scenariuszy skali redukcji emisji gazów cieplarnianych generowanych przez rolnictwo przeprowadzone przez Fellmanna i in. (2015) wskazują, iż konieczność ograniczenia emisji dotknie w odmiennym stopniu poszczególne typy gospodarstw rolnych. Najbardziej odczują to gospodarstwa specjalizujące się w hodowli bydła. Jednocześnie jednak poziom dochodów większości rolników wzrósłby. Wyjątkiem byliby między innymi producenci z Irlandii.

Nakładając jakiekolwiek ograniczenia czy wymogi dotyczące emisji gazów cieplarnianych, należy jednak mieć na uwadze skalę zanieczyszczeń generowanych przez poszczególne gospodarstwa. W związku z tym procedura wdrożenia systemu ograniczenia emisji gazów w rolnictwie powinna uwzględniać następujące elementy: identyfikację gospodarstw emitujących najwięcej gazów cieplarnianych, określenie najlepszych rozwiązań służących ograniczeniu emisji gazów przez te gospodarstwa, wybór najlepszych rozwiązań z punktu widzenia ich efektywności kosztowej (Franks, Hadingham, 2012, s. 727).

Kolejną kwestią jest dostęp do wiedzy na temat sposobów ograniczania emisji gazów. Warto także zwrócić uwagę na to, iż ograniczenie emisji gazów cieplarnianych może pozytywnie wpływać na wyniki ekonomiczne gospodarstwa. Wskazują na to między innymi rezultaty badań dotyczących gospodarstw rolnych specjalizujących się w uprawach polowych przeprowadzone przez Zielińskiego (2016). Jednak autor ten zauważa, że ograniczanie emisji zanieczyszczeń do atmosfery tylko do pewnej granicy dodatnio wpływa na wyniki ekonomiczne i rozwój gospodarstwa, 
zaś powyżej tej granicy cele ekonomiczne i środowiskowe przestają być komplementarne względem siebie.

Mając na uwadze ograniczenia i uwarunkowania dotyczące emisji gazów cieplarnianych w niezwykle zróżnicowanym rolnictwie Unii Europejskiej, należy poszukać mechanizmu redukcji tych emisji, który mógłby być wdrożony w całym sektorze rolnym. Wydaje się, że najprostszym tego typu rozwiązaniem jest powiązanie wymogów odnoszących się do ograniczenia emisji z płatnościami bezpośrednimi, które są jedynym działaniem Wspólnej Polityki Rolnej (WPR) obejmującym cały unijny sektor rolny.

Tego typu rozwiązanie nie byłoby niczym nowym, jeśli chodzi o powiązanie płatności bezpośrednich z określonymi wymogami dotyczącymi ochrony środowiska. Płatności bezpośrednie są od dłuższego czasu powiązane z tak zwanymi wymogami wzajemnej zgodności, z których wiele dotyczy ochrony środowiska, zaś od ostatniej reformy WPR wypłata części środków uzależniona jest od spełnienia określonych wymogów odnoszących się do sposobu produkcji i wykorzystania posiadanych użytków rolnych, czyli tak zwanego zazielenienia płatności. Ma ono formę płatności z tytułu praktyk rolniczych korzystnych dla klimatu i środowiska. Artykuł 43 rozporządzenia UE nr 1307/2013 określa, jakie są to praktyki, a poszczególne państwa członkowskie miały na mocy tego rozporządzania również możliwość określenia, które inne praktyki rolnicze można uznać za równoważne. Wybrane praktyki i sposób wdrożenia zazielenienia są często krytykowane, gdyż uznaje się, iż ostateczny kształt wymogów został rozmyty w stosunku do pierwotnej propozycji Komisji Europejskiej, a ich wpływ na faktyczny stan środowiska będzie niedostrzegalny (Erjavec, Lovec, Erjavec, 2015). Jednak nie oznacza to, że niemożliwe jest wprowadzenie efektywnego systemu ograniczania emisji gazów cieplarnianych w rolnictwie na podstawie wymogów powiązanych z płatnościami bezpośrednimi. Może to być zresztą pierwszy krok do wprowadzenia w przyszłości rynkowych mechanizmów redukcji emisji zanieczyszczeń w odniesieniu do największych emitentów.

Jak wskazują badania między innymi Pizera (1999), najlepszą metodą redukcji gazów cieplarnianych jest wdrożenie podatku od wprowadzanych do atmosfery zanieczyszczeń, jednak to rozwiązanie nie jest możliwe do wprowadzenia w Unii Europejskiej ani w odniesieniu do rolnictwa, ani żadnego innego sektora $\mathrm{z}$ uwagi na konieczność jednomyślności państw członkowskich wymaganej przy decyzjach z zakresu polityki fiskalnej. Za korzystniejsze niż nakazy i kontrole uważa się także 
rozwiązania rynkowe (Bakam, Balana, Matthews, 2012, s. 33), które wymagają jednak znacznego zaangażowania objętych nimi podmiotów w zapoznanie się z mechanizmami funkcjonowania tego typu rozwiązań, na co potrzeba czasu i odpowiednio przygotowanej kampanii informacyjnej. Należy również uwzględnić fakt, iż koszty transakcyjne związane na przykład z handlem prawami do emisji dotyczą nie danej ilości emitowanych gazów, lecz są ponoszone przez dane gospodarstwo rolne. Taki system jest znacznie kosztowniejszy dla małych podmiotów o niewielkim celu redukcyjnym (Bakam i in., 2012, s. 43).

\section{Podsumowanie}

Istnieje wiele innych mechanizmów ograniczania emisji, które mogą być zastosowane w rolnictwie, jednak należy pamiętać o tym, iż nie wszystkie metody, co do których istnieją techniczne możliwości wdrożenia, są możliwe do realizacji pod względem efektywności realizacji i/lub decyzji o charakterze politycznym, na które wpływają różnorakie czynniki.

Ponadto należy mieć na uwadze fakt, iż wdrożenie któregokolwiek z nich obarczone jest dużą niepewnością co do rzeczywistych skutków. Chodzi przede wszystkim o efekt wycieku i przesunięcia emisji zanieczyszczeń, które są trudne do prognozowania. Dodatkowym utrudnieniem jest zróżnicowanie sektora rolnego wymuszające stosowanie kombinacje różnych działań, co prowadzi do konieczności badania wzajemnych relacji między wdrażanymi instrumentami.

Dokonując oceny różnych metod ograniczania emisji gazów cieplarnianych przez unijne rolnictwo, należy także dokonać analizy ewentualnego zróżnicowania regionalnego kosztów redukcji tych emisji. Najczęściej stosowaną metodą jest tutaj analiza krzywej marginalnych kosztów obniżania emisji (marginal abatement cost curve - MACC) (Eory i in., 2013, s. 55). W przypadku znaczących różnic w poziomie kosztów redukcji należy uwzględnić to w tworzeniu mechanizmu redukcji emisji gazów.

Podsumowując, należy podkreślić, że mając na uwadze wprowadzone w ramach ostatniej reformy WPR tak zwane zazielenienie płatności bezpośrednich, za najlepszy pod względem polityczno-organizacyjnych możliwości wdrożenia należy uznać mechanizm redukcji emisji zanieczyszczeń powiązany z uzyskiwaniem płatności bezpośrednich. Jest to tym łatwiejsze do zrealizowania, że wniosek po płat- 
ność zawiera wiele informacji pozwalających oszacować zakres emisji gazów cieplarnianych generowanych przez dane gospodarstwo. Rozwiązanie to ma ponadto dodatkową zaletę $\mathrm{w}$ postaci zachęcenia rolników do uwzględniania kwestii emisji zanieczyszczeń w swojej działalności rolniczej.

\section{Literatura}

Bakam, I., Balana, B.B., Matthews, R. (2012). Cost-Effectiveness Analysis of Policy Instruments for Greenhouse Gas Emission Mitigation in the Agricultural Sector. Journal of Environmental Management, 112, 33-44.

Domínguez, I.P., Fellmann, T., Witzke, H.-P., Jansson, T., Oudendag, D., Gocht, A., Verhoog, D. (2012). Agricultural GHG Emissions in the EU: An Exploratory Economic Assessment of Mitigation Policy Options. Luxemburg: Publications Office of the European Commission.

Eory, V., Topp, C., Moran, D. (2013). Multiple-Pollutant Cost-Effectiveness of Greenhouse Gas Mitigation Measures in the UK Agriculture. Environmental Science \& Policy, 27, $55-67$.

Erjavec, E., Lovec, M., Erjavec, K. (2015). From "Greening" to "Greenwash": The Drivers of the CAP "Reform". W: J. Swinnen (red.), The Political Economy of the 2014-2020 Common Agricultural Policy an Imperfect Storm (s. 215-276). London: Rowman and Littlefield International.

European Commission (2015a). Consultation on Addressing Greenhouse Gas Emissions from Agriculture and LULUCF in the Context of the 2030 EU Climate and Energy Framework. Pobrane z: http://ec.europa.eu/clima/consultations/articles/0026_en.htm (10.05.2016).

European Commissiom (2015b). EU ETS Handbook. Brussels.

Fellmann, T., Van Doorslaer, B., Witzke, P., Huck, I., Weiss, F., Salputra, G., Jansson, T., Drabik, D., Leip, A. (2015). An Economic Assessment of GHG Mitigation Policy Options for EU Agriculture. Luxemburg: Publications Office of the European Commission.

Franks, J.R., Hadingham, B. (2012). Reducing Greenhouse Gas Emissions from Agriculture: Avoiding Trivial Solutions to a Global Problem. Land Use Policy, 29, 727-736.

IPCC (2006). 2006 IPCC Guidelines for National Greenhouse Gas Inventories. Pobrane z: http://www.ipcc-nggip.iges.or.jp/public/2006gl/index.html (10.05.2016).

Komisja Europejska (2015). Komunikat Komisji do Parlamentu Europejskiego, Rady, Europejskiego Komitetu Ekonomiczno-Społecznego i Komitetu Regionów. Program prac Komisji na 2016 r. Czas na nieprzeciętne działania. COM(2015) 610 final. 
Laing, T., Sato, M., Grubb, M., Comberti, C. (2014). The Effects and Side-Effects of the EU Emissions Trading Scheme. Wiley Interdisciplinary Reviews: Climate Change, $5,4,509-519$.

MacLeod, M., Eory, V., Gruère, G., Lankoski, J. (2015). Cost-Effectiveness of Greenhouse Gas Mitigation Measures for Agriculture: A Literature Review. OECD Food, Agriculture and Fisheries Papers, 89.

Pizer, W.A. (1999). The Optimal Choice of Climate Change Policy in the Presence of Uncertainty. Resource and Energy Economics, 21, 3-4, 255-287.

Rozporządzenie Parlamentu Europejskiego i Rady (UE) nr 1307/2013 z 17.12.2013 ustanawiające przepisy dotyczące płatności bezpośrednich dla rolników na podstawie systemów wsparcia w ramach wspólnej polityki rolnej oraz uchylające rozporządzenie Rady (WE) nr 637/2008 i rozporządzenie Rady (WE) nr 73/2009. Dz.U. UE L 347.

Zieliński, M. (2016). Emisja gazów cieplarnianych a wyniki ekonomiczne gospodarstw specjalizujacych się $w$ uprawach polowych. Warszawa: Instytut Ekonomiki Rolnictwa i Gospodarki Żywnościowej - Państwowy Instytut Badawczy.

\title{
WHAT MECHANISM LEADING TO REDUCTION OF GREENHOUSE GAS EMISSIONS SHOULD BE APPLIED IN THE CASE OF THE EU AGRICULTURE?
}

\begin{abstract}
Agriculture is the main emitter of greenhouse gases other than $\mathrm{CO}_{2}$. Therefore in the coming years also this sector is planned to be included in the effort of reducing GHG emissions. This paper is aimed at presenting the scale and specificity of GHG emissions in the EU agriculture and at assessing which mechanism of reduction of GHG emissions would be the best suited to agriculture taking into account its specific features. The study is based on meta-analysis of the results of a number of studies related to reduction of GHG emissions. The results show that the European Trading System applied to other sectors seems not to be a suitable solution for the whole EU agriculture. The best solution would be to apply a set of several measures adjusted to the size and character of GHG emissions of a given farm.
\end{abstract}

Keywords: agriculture, greenhouse gas emissions, European Union

JEL codes: Q52, Q53, Q10 
